\title{
Studies of antagonistic effect between Lactobacillus sakei on Escherichia coli, Listeria monocytogenes and Staphylococcus aureus
}

\author{
Augustus Caeser Franke Portella ${ }^{1^{*}}$, Raimundo Wagner de Souza Aguiar ${ }^{1}$, Jefferson da Luz \\ Costa $^{1,2}$, André Luís Lopes da Silva ${ }^{2}$ and Gessiel Newton Scheidt ${ }^{1}$ \\ ${ }^{1}$ Departamento de Ciências Agrárias e Tecnológicas; Universidade Federal do Tocantins; 77402-970; Gurupi - TO \\ - Brasil. \\ ${ }^{2}$ Departamento de Engenharia de Bioprocessos e Biotecnologia; Universidade Federal do Paraná; 81531-970; \\ Curitiba - PR - Brasil.
}

\begin{abstract}
The antimicrobial activity of a commercial probiotic culture, Lactobacillus sakei(ATCC 1521) at following concentrations $\left(30,42,60,78\right.$ and $\left.90 \mu \mathrm{g} / \mathrm{ml}, 10^{5}-10^{7} \mathrm{UFC} / \mathrm{mL}\right)$, temperatures of interaction $\left(4,10,20,30,37^{\circ} \mathrm{C}\right)$ and initial $\mathrm{pH}$ (3.5, 4.0, 4.5, 5.0 and 5.5) were tested against three foodborne pathogens, Escherichia coli, Listeria monocytogenesand Staphylococcus aureus. The antagonistic effect of the probiotic culture in vitro was performed by liquid microdilution method. The results indicated that the inhibitory substance present on a 24 hours culture broth could be an advantage when keeping the culture dominant during longer fermentations. For the highest lactic acid production, the incubation period of lactic acid bacteria $(1.04 \% \mathrm{v} / \mathrm{v})$ was on MRS Broth in aerobic conditions, at $37^{\circ} \mathrm{C} / 24$ hours, which gave a minimum $\mathrm{pH}$ value of the supernatant (3.5). The data suggest that supernatant can have significant bacteriostatic activity against $\mathrm{E}$. coli, $\mathrm{L}$. monocytogenesand $\mathrm{S}$. aureus, and may provide curedmeats with a degree of protection against this microorganism, particularly if employed with a combination of acid $p H$, and adequate refrigeration.
\end{abstract}

Key words: Antimicrobial activity, complex substrates, surface response

\section{INTRODUCTION}

In studies carried out on the effect and the way of action of substances with antimicrobial activity present on foods or added properties during the manufacture process, can be perceived that the behavior of microorganism are determined by the specific characteristic of the culture conditions (i.e. water activity, temperature and $\mathrm{pH}$ ) and, also, for those inherent ones to the effect of the added cultures (Hurst, 1983).

The lactic acid bacteria (LAB) are examples of these cultures that not only have sensorial characteristics, but also allow a better conservation of foods being able to be used as probiotics also alive bacteria in foods that after the ingestion exerts beneficial effects to the host. The way of action of probiotics is still unknown, however, some researches (Parker, 1974; Shah, 2000;Cebeci and Guarakan, 2003) are suggesting some processes that can act independently or associated.
A previous study showed the competitive exclusion, in which the probiotic would compete with pathogens for nutritional sources, hindering its action. The microorganisms most commonly found in foods with probiotic action are the lactobacilli and the bifidobacteria.

There is a recommendation regarding human consumption food, indicating approximately $10^{6}$ living microorganism per gram or $\mathrm{mL}$ of the product, at the moment of the consumption, for the probiotic to produce therapeutically benefits (Klaenhammer, 2001). LAB are characterized as Gram positive, not sporulant, normally not-mobile and they produce lactic acid during the fermentation processes using glucose. They grow anaerobically, however most of them are not sensible to $\mathrm{O}_{2}$ presence and can grow under aerobic conditions also. Thus, they are called anaerobic aerotolerant (Brock et al., 1994).The monitoring of the microbial grow is the aim of

Author for correspondence: caesar_portella@hotmail.com

J. Biotec. Biodivers. v. 3, N.1: pp. 10-17, Fev. 2012

https://doi.org/10.20873/jbb.uft.cemaf.v3n1.portella 
many researchers in the area of biotechnology being the majority, based on statistical models laws of probabilities, looking for parametrizing the sequence of identification, isolation and quantification of bacteriocin inhibiting activity in different physical-chemical and environmental conditions (Vandenbergh, 1993; Koutsoumanis and Sofos, 2005). The adjust method commonly used the univaried method, in which a factor varies during evaluation time. However, this method presents disadvantages and is being gradually substituted by multivaried methods, in which diverse factors are evaluated simultaneously.

To combine statistical techniques to a biological interpretation is essential to describe and understand biological systems. A clear example is the kinetic of growth and the inhibition of microorganism in a culture medium (Jarvis, 1989). There are situations that the use of multivaried methods becomes particularly important in industrial conditions and routine analysis, therefore they imply in time and costs, so such method is suitable for these applications only. The methodology of replying surfaces involves the use of factorial planning that can be repeated some times, drawing the response surface to the direction of the region desired point of excellence.

\section{MATERIAL AND METHODS}

\section{Microorganisms strains}

The strainsused in this study were obtained from American Type Culture Collection (ATCC): Lactobacillussakei (ATCC 1521), Listeriamonocytogenes (ATCC 15313), Escherichia coli (ATCC 25922) and Staphylococcusaureus (ATCC 25923).

\section{Media}

The putative strain able to inhibit the pathogens, Lactobacillus sakei, was cultivated in MRS agar with $0.3 \%$ ofaniline blue solution. L. sakei colonies have the ability of metabolize aniline blue, being this the way to recognizing their morphologic characteristics (Silva et al., 2001).The plates were incubated at $37^{\circ} \mathrm{C}$ for $24 \mathrm{~h}$ for forward studies of its morphologic characteristics.

In order to activate the pathogens $(L$. monocytogenes, E. coli and $S$. aureus), they were sown from the agar nutrient into test tubes containing $5 \mathrm{~mL}$ ofMueller Hinton broth(MH
Broth), with the aid of a platinum holder, and incubated at $30-37{ }^{\circ} \mathrm{C}$ for 24 hours. After the incubation period, serial dilutions were performed in which the inoculum was diluted in peptoned water $0.1 \%$, until the desired concentration ofeach microorganism.

\section{Effect of $\mathrm{pH}$, heat treatment and cooling on antagonistic activity}

To evaluate the thermal stability at different $\mathrm{pH}$ values $(3.5,4.0,4.5,5.0$ and 5.5), supernatant cultures of $L$. sakeiwere submitted to thermal treatments $\left(20{ }^{\circ} \mathrm{C} / 24 \mathrm{~h}, 30{ }^{\circ} \mathrm{C} / 24 \mathrm{~h}, 37{ }^{\circ} \mathrm{C} / 24 \mathrm{~h}\right)$ and refrigeration $\left(3{ }^{\circ} \mathrm{C} / 24 \mathrm{~h}, 10^{\circ} \mathrm{C} / 24 \mathrm{~h}\right)$. The $\mathrm{pH}$ was adjusted to their respective values using solutions of $\mathrm{NaOHorHCl} 1 \mathrm{~N}$.

\section{Inhibitory activity}

The antagonistic effect against the target microorganisms was determined, initially, in 1.5 $\mathrm{mL}$ cuvette at O.D.660nm using spectrophotometer (Spectrumlab 22PC). The supernatant was added in equal volume of Mueller-Hinton broth.

Then, they were inoculated with $2 \%(\mathrm{v} / \mathrm{v})$ of the indicator microorganism previously reactivated in $\mathrm{MH}$ broth and incubated at $37{ }^{\circ} \mathrm{C}$ overnight. The control sample was composed by MH:MRS (Man et al., 1961) broth in 1:1 ratio inoculated with $2 \%$ of indicator microorganism culture, incubated at $37^{\circ} \mathrm{C}$ during 24 hours.

A second evaluation was performed on microplates by microdilution broth technique on a wavelength of $660 \mathrm{~nm}$ using BioTek equipment, model "Power Wave XS" and the KC Junior program.

The supernatant was added in equal volume of $\mathrm{MH}$ broth and inoculated with $10 \%(\mathrm{v} / \mathrm{v})$ of microorganism previously reactivated in $\mathrm{MH}$ broth, incubated at $37{ }^{\circ} \mathrm{C}$, during overnight and diluted 1:10 (MH broth: distilled water). MH:MRS broth in ratio 1:1 was used as blank and a control was made with MH:MRS (1:1) inoculated with $10 \%(\mathrm{v} / \mathrm{v})$ of each target microorganism. The temperature range of incubation experiments were of two types: those conducted at a single cooling rate and those conducted at two cooling rates. The dual-rate experiments followed one cooling rate from $3{ }^{\circ} \mathrm{C}$ to $20{ }^{\circ} \mathrm{C}$ and a second rate from $20{ }^{\circ} \mathrm{C}$ to $37^{\circ} \mathrm{C}$.

The inhibition of the growth of the target microorganism occurred when the absorbance was 
lower than the control absorbance, indicating that the microorganism had a reduction of its growth in relation to the control, after 24 hours of incubation (Chang et al., 2001).

\section{Statistical assessment}

To maximize the antagonism effect of Lactobacillus sakei supernatants a Full Factorial Design for three independent variables was adopted. The Experimental Design was based on Statistica5.0 (StatSofts Inc., Tulsa, OK, USA). Full Factorial Design was used to obtain the combination of values that can optimize the response within the region of the three dimensional observation spaces, which allows one to design a minimal number of experimental runs
(Box et al., 1978). The variables were supernatant concentration of Lactobacillus sakei, the temperature and $\mathrm{pH}$, were submitted for the analysis in the design.

The variable of each constituent at levels $-1.68,-$ 1,0 and $+1,+1.68$ is given in Table 1 . The selection of low, middle and high levels for all these variables were based on a prior screening done in our laboratory (unpublished data). A $2^{3}$ full factorial design with using one central point and two axial points for each variable totalizing 15 experiments. The behavior of the present system described by the following equation 1, which includes all interaction terms regardless of their significance:

$$
\hat{y}=b_{o}+b_{1} x_{1}+b_{2} x_{2}+b_{3} x_{3}+b_{12} x_{1} x_{2}+b_{13} x_{1} x_{3}+b_{23} x_{2} x_{3}
$$

Where $\hat{y}$ is predicted response, i.e.absorbance values; $\mathrm{x}_{1}, \mathrm{x}_{2}$ and $\mathrm{x}_{3}$ are independent variables; $\mathrm{b}_{0}$ is coefficient constant for offset term; $b_{1}, b_{2}$ and $b_{3}$ are coefficient constant for linear effects and $b_{12}, b_{13}$, $b_{23}$ are coefficient constant for interactions effects. The model evaluates the effect of each independent variable to a response. The variables studied were supernatant $(30,42,60,78,90$ $\mu \mathrm{g} / \mathrm{mL})$, temperature $\left(3,10,20,30,37^{\circ} \mathrm{C}\right)$ and $\mathrm{pH}(5.0,5.5,6.0,6.5,7.0)$.
The analysis of the factorial planning consists of quantifying the effect of the factors on one determined reply. The studied variables were supernatant concentration of Lactobacillus sakei, the temperature and $\mathrm{pH}$, in its levels minimum and maximum (Table 1) correspond to the variable $\mathrm{x}_{1}$, $\mathrm{x}_{2}$ and $\mathrm{x}_{3}$ respectively in the analysis of time of life of microorganism L. monocytogenes, E. coli and S. aureus.

Table 1. Optimization of physical condition for the antagonic effect of supernatants Lactobacillus sakei: independent variables in a $2^{3}$ full factorial experiment desing. The parameters used in this experiment are supernatant, temperature and $\mathrm{pH}$.

\begin{tabular}{ccccccc}
\hline \multicolumn{7}{c}{ Actual factor level at coded factor level of } \\
Factor & Symbol & $\mathbf{- 1 . 6 8}$ & $\mathbf{- 1}$ & $\mathbf{0}$ & $\mathbf{+ 1}$ & $\mathbf{+ 1 . 6 8}$ \\
\hline Supernatant $(\mu \mathrm{g} / \mathrm{ml})$ & $\mathrm{X}^{1}$ & 30 & 42 & 60 & 78 & 90 \\
Temperature $\left({ }^{\circ} \mathrm{C}\right)$ & $\mathrm{X}^{2}$ & 3 & 10 & 20 & 30 & 37 \\
$\mathrm{pH}$ & $\mathrm{X}^{3}$ & 5.0 & 5.5 & 6.0 & 6.5 & 7.0 \\
\hline
\end{tabular}

\section{Surface response and optimal bacterial growth}

Surface response represents three-dimensional graphic which show the variation of the experimental reply in function of alterations in the levels of two selected variable, as for example, the temperature and $\mathrm{pH}$. There will have other variable and it will be fixed in one determined level and the equation will have to be rearranged to get it respective reply surface. In the case of equations 1 , the variable $\mathrm{x}_{3}$ was fixed in level zero (in spaced out terms), correspondent to the central point, but it could have been fixed in any another level of interest. The use of level zero does not mean, however, that $\mathrm{pH}$ was adjusted for this value, on the other hand, in the level zero $\mathrm{pH}$ of the supernatant was adjusted for was of 5.5, thus the equation is simplified and allows the representation in three dimensions. 


\section{RESULTS AND DISCUSSION}

The supernatant of $L$. sakeipresented different sensitivities to temperature and $\mathrm{pH}$, this trial evaluated the effects of different values of $\mathrm{pH}$ (from 3.5 to 5.5 ), cooling temperatures $\left(4{ }^{\circ} \mathrm{C}\right.$ during $24 \mathrm{~h}, 10^{\circ} \mathrm{C}$ during $24 \mathrm{~h}$ ) and heat treatment $\left(20{ }^{\circ} \mathrm{C}\right.$ during $24 \mathrm{~h}, 30{ }^{\circ} \mathrm{C}$ during $24 \mathrm{~h}, 37{ }^{\circ} \mathrm{C}$ during $24 \mathrm{~h}$ ) (Table 2).

Table 2. Effect of $\mathrm{pH}$ and temperature on the absorbance of supernatantofLactobacillus sakei.

\begin{tabular}{ccccccc}
\hline & & \multicolumn{5}{c}{ Absorbance results } \\
$\mathbf{p H}$ & Control & $\mathbf{4}^{\circ} \mathbf{C} / \mathbf{2 4 h}$ & $\mathbf{1 0}^{\circ} \mathbf{C} / \mathbf{2 4 h}$ & $\mathbf{2 0}^{\circ} \mathbf{C} / \mathbf{2 4 h}$ & $\mathbf{3 0}^{\circ} \mathbf{C} / \mathbf{2 4 h}$ & $\mathbf{3 7}^{\circ} \mathbf{C} / \mathbf{2 4 h}$ \\
\hline 5.5 & 0.350 & 0.356 & 0.527 & 0.543 & 0.623 & 0.560 \\
5.0 & 0.389 & 0.402 & 0.508 & 0.604 & 0.645 & 0.545 \\
4.5 & 0.540 & 0.518 & 0.538 & 0.558 & 0.548 & 0.560 \\
4.0 & 0.640 & 0.494 & 0.623 & 0.521 & 0.622 & 0.538 \\
3.5 & 0.639 & 0.582 & 0.601 & 0.595 & 0.597 & 0.585 \\
\hline
\end{tabular}

The number of cells of L. monocytogenes, E. coli and $S$. aureus presented in sample test (inoculated with the crop of $L$. sakei), as well in the sample control (not inoculated with the culture L. sakei), showed little variation until the third hour (Figure 1). From the sixth hour of inoculation was observed that the population of pathogenic microorganism showed an increase in the counting of control samples for the test samples.

During lactic acid bacteria growth, it was observed a $\mathrm{pH}$ value drop, turning the environment very acid, probably due to production lactic acid. It can be determined the inhibition of other microorganism. The results of the growth of $L$. sakei in MRS broth, to $37{ }^{\circ} \mathrm{C}$ in aerobic, had a minimum value of the $\mathrm{pH}$ supernatant, around 3.90, after 24 hours of incubation. The maximum production of lactic acid verified, came after the same period of growing, reaching $1.04 \mathrm{~g} \%$ (120 $\mathrm{mmol}$ ) of acid lactic in the supernatant. Figure 1 show values of $\mathrm{pH}$ during the period of lactic bacteria incubation.

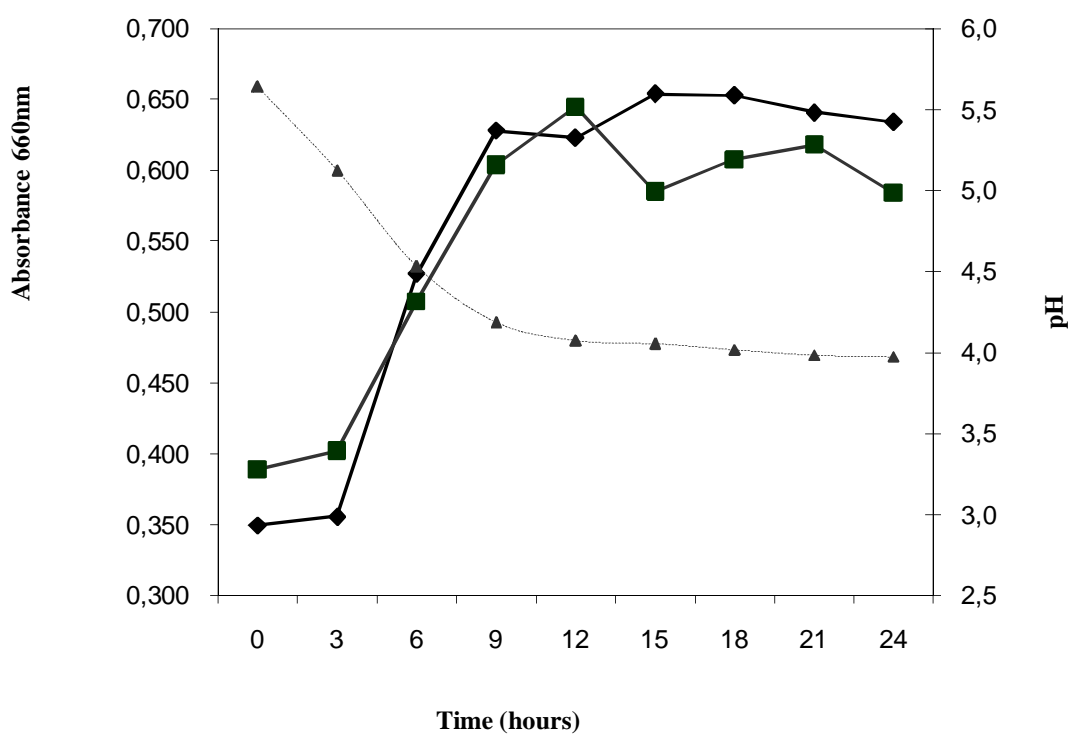

Figure 1- Kinetics of pathogenic growth. 
Fractionary matrix planning (Table 3) was from three variables $\mathrm{x}_{1}, \mathrm{x}_{2}$ and $\mathrm{x}_{3}$. constructed from a complete factorial planning

Table 3. Experimental design with experimental and predict values of pathogenics growth.

\begin{tabular}{|c|c|c|c|c|c|c|c|}
\hline \multirow[t]{2}{*}{ Run } & \multirow{2}{*}{$\begin{array}{c}\text { Supernatant } \\
\mathrm{X}_{1}\end{array}$} & \multirow{2}{*}{$\begin{array}{c}\text { Temperature } \\
\mathbf{X}_{2}\end{array}$} & \multirow{2}{*}{$\begin{array}{l}\mathrm{pH} \\
\mathbf{X}_{3}\end{array}$} & \multicolumn{3}{|c|}{ Factors } & \multirow{2}{*}{$\begin{array}{l}\text { O.D.660nn } \\
24 h\end{array}$} \\
\hline & & & & $\mathbf{X}_{1}$ & $\overline{X_{2}}$ & $\mathbf{X}_{\mathbf{3}}$ & \\
\hline 1 & 42 & 10 & 5.5 & -1 & -1 & -1 & 0.506 \\
\hline 2 & 78 & 10 & 5.5 & +1 & -1 & -1 & 0.519 \\
\hline 3 & 42 & 30 & 5.5 & -1 & +1 & -1 & 0.509 \\
\hline 4 & 78 & 30 & 5.5 & +1 & +1 & -1 & 0.531 \\
\hline 5 & 42 & 10 & 6.5 & -1 & -1 & +1 & 0.506 \\
\hline 6 & 78 & 10 & 6.5 & +1 & -1 & +1 & 0.513 \\
\hline 7 & 42 & 30 & 6.5 & -1 & +1 & +1 & 0.525 \\
\hline 8 & 78 & 30 & 6.5 & +1 & +1 & +1 & 0.625 \\
\hline 9 & 30 & 20 & 6.0 & -1.68 & 0 & 0 & 0.513 \\
\hline 10 & 90 & 20 & 6.0 & 1.68 & 0 & 0 & 0.619 \\
\hline 11 & 60 & 3 & 6.0 & 0 & -1.68 & 0 & 0.520 \\
\hline 12 & 60 & 37 & 6.0 & 0 & 1.68 & 0 & 0.621 \\
\hline 13 & 60 & 20 & 5.0 & 0 & 0 & -1.68 & 0.505 \\
\hline 14 & 60 & 20 & 7.0 & 0 & 0 & 1.68 & 0.587 \\
\hline 15 & 60 & 20 & 6.0 & 0 & 0 & 0 & 0.655 \\
\hline
\end{tabular}

This study emphasized the statistic experimental analysis (the significance of the factors were tested using the analysis of variation, F-test and ttest), the use of the graphic method (Pareto's chart) and the interpretation of the interactions among variables. Through these results, if necessary, the model was refined, excluding irrelevant variables. Pareto's chart (Figure 2) showed that the model needed adjustment in terms of supernatants, temperature and $\mathrm{pH}$, a variation towards lower $\mathrm{pH}$ was found to be necessary (since the $\mathrm{pH}$ bar crossed the red pointed line indicating that this result is not within the $95 \%$ confidence level).

These results can be attributed to the levels of variables, which were probably close to optimal levels. The distance between the quantitative lower (-) and the highest level (+) of both variables, was probably insufficient to promote significant differences. However, by the evaluation of the values of extinction, growth in all microbiological testing of samples in the central point (test 15) of planning (Table 2), especially in relation to the attributes temperature and $\mathrm{pH}$, are noticed.

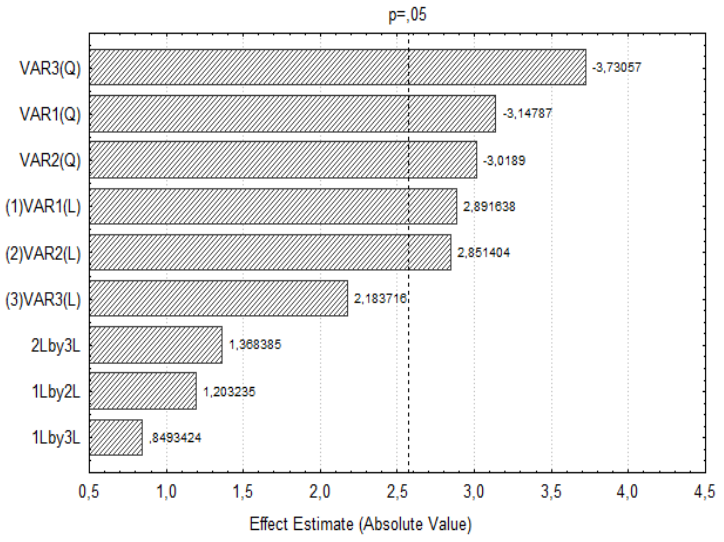

Figure 2 -Paretto’s charts.

The model was optimized using the values of absorbance as described in (Table 4). ANOVA was used for the adjustment of the variance model analysis and to verify the significance of the regression and if exist evidences of lack of adjustment. The results of variance analysis (ANOVA) to describe answers are showed in (Table 5), where it can be noticed the correlation coefficient and the percentage of variance, explaining $89,07 \%$ of variance. 
Table 4.Variance analysis (ANOVA) for the factorial design

\begin{tabular}{lccccc}
\hline $\begin{array}{c}\text { Source of } \\
\text { Variation }\end{array}$ & $\begin{array}{c}\text { Sum of } \\
\text { Square }\end{array}$ & $\begin{array}{c}\text { Degrees of } \\
\text { Significance }\end{array}$ & $\begin{array}{c}\text { Mean } \\
\text { Square }\end{array}$ & $\begin{array}{c}\text { F-ratio } \\
\text { (model Significance) }\end{array}$ & p-value \\
\hline (1) Supernatant(L) & 0.007508 & 1 & 0.007508 & 8.38159 & 0.033984 \\
Supernatant(Q) & 0.008916 & 1 & 0.008916 & 9.95268 & 0.025243 \\
(2) Temperature(L) & 0.007303 & 1 & 0.007303 & 8.15274 & 0.035602 \\
Temperature(Q) & 0.008191 & 1 & 0.008191 & 9.14362 & 0.029287 \\
(3) pH (L) & 0.004284 & 1 & 0.004284 & 4.78166 & 0.080431 \\
(3) pH (Q) & 0.012509 & 1 & 0.012509 & 13.96342 & 0.13476 \\
1(L) by 2(L) & 0.001301 & 1 & 0.001301 & 1.45173 & 0.282162 \\
1(L) by 3(L) & 0.00648 & 1 & 0.00648 & 0.72336 & 0.433874 \\
2(L) by 3(L) & 0.001682 & 1 & 0.001682 & 1.87760 & 0.228928 \\
\hline Error & 0.004479 & 5 & 0.000896 & & \\
Total SS & 0.040983 & 14 & & &
\end{tabular}

Table 5. Factorial designs main effects and interactions analysis for antagonistic between Lactobacillus sakei on Escherichia coli, Listeria monocytogenes and Staphylococcus aureus

\begin{tabular}{lcccc}
\hline \multicolumn{1}{c}{ Factor } & Effect & Std. Error & t-value & p-value \\
\hline Mean/Interc. & 0.660089 & 0.029743 & 22.19310 & $0.000003^{* *}$ \\
(1) Supernatant(L) & 2.891638 & 0.016205 & 2.89510 & $0.033984^{* *}$ \\
Supernatant(Q) & -3.14787 & 0.024352 & -3.15479 & $0.025243^{* *}$ \\
(2) Temperature(L) & 2.851404 & 0.016205 & 2.85530 & $0.035602^{* *}$ \\
Temperature(Q) & -3.0189 & 0.024352 & -3.02384 & $0.029287^{* *}$ \\
(3) pH (L) & 2.183716 & 0.016205 & 2.18670 & 0.080431 \\
(3) pH (Q) & -3.73057 & 0.024352 & -3.73677 & $0.013476^{* *}$ \\
1(L) by 2(L) & 1.203235 & 0.021164 & 1.20488 & 0.282162 \\
1(L) by 3(L) & 0.8493424 & 0.021164 & 0.85050 & 0.433874 \\
2(L) by 3(L) & 1.368385 & 0.021164 & 1.37025 & 0.228928 \\
\hline
\end{tabular}

$(\mathrm{L})$ : linear factor; $(\mathrm{Q})$ : quadratic factor; *Significant factors $(\mathrm{p}<0.05)$; **Significant factors $(\mathrm{p}<0.10)$.

After the calculation of coefficient errors and reliable intervals, it was verified in the below equation that describes the power of inhibition in these conditions:

$$
\hat{y}=-0.66-2.916 x_{1}-3.14787 X_{1}{ }^{2}+2.8514 x_{2}-3.0189 X_{2}{ }^{2}-3.73057 x_{3}{ }^{2}
$$

Thus, one can say that this model showed no statistical significance and that it cannot be used for predictive purposes.

The scale of Figure 3clearly shows the relation among temperature in its higher level $\left(37^{\circ} \mathrm{C}\right)$ and the concentration of the supernatant used in both the levels. Both variable influenced positively in the increase of the absorbance causing a reduction in kinetic of the growth of the microorganism when using refrigeration temperature $\left(8^{\circ} \mathrm{C}\right)$, and the supernatant in its lesser precipitated concentration can be noticed of $(30 \mathrm{~mL})$.

Also in Figure 2, the Zaxis refers to predict absorbance yield, values in contour plot represent absorbance gradients for corresponding supernatant and temperature level. Hollow squares in surface plot represent values of supernatant and temperature for corresponding experiments.

As from the data of Table 2 is possible verify that the increase in some of the variable will not increase the value of the analytical reply, will not be necessary to carry out an ascension to the maximum to locate the excellent experimental conditions, therefore these already are enclosed in our planning. It is now enough to select the condition where the difference enters the answers of the adjusted models is maximum, this can directly be made using equations 2 and 3 (this 
comparison is facilitated, therefore the error standard of the coefficients of the model is very next), or with the aid of (Figure 4).

The more favorable experimental condition for the analytical reply is to use the lesser concentration of the variable $\mathrm{x}_{3}(\mathrm{pH})$ since in the tested interval, the increase in the levels of this changeable only increases the values of absorbance. Thus, we can use level -1 (that correspond pH 5).

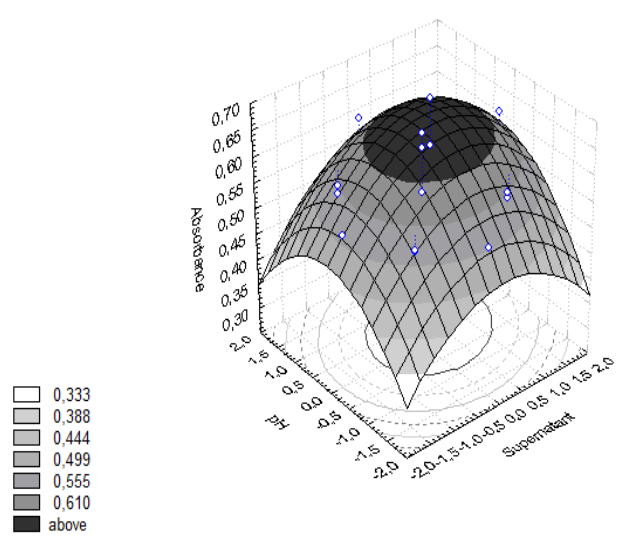

Figure 3 - Response surface plot describing effect of supernatant and temperature $\left({ }^{\circ} \mathrm{C}\right)$.

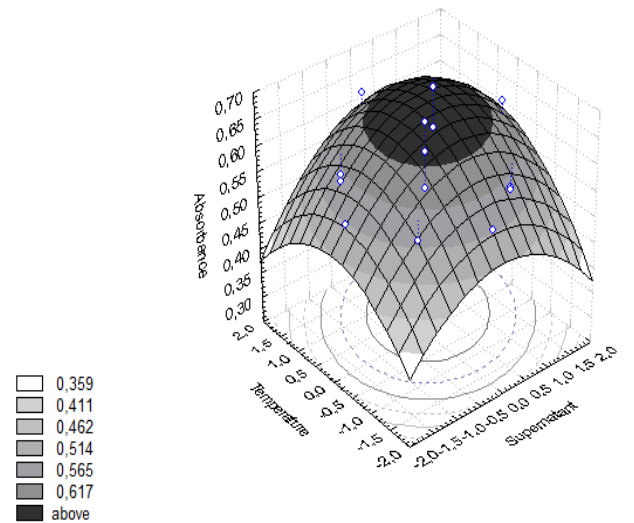

Figure 4- Response surface plot describing effect of supernatant and $\mathrm{pH}$.

Another possibility is to raise the levels of the variable that contributes more for the increase of the analytical reply (bigger coefficient in the equation or greater inclination the reply surface). In this in case that, $x_{1}$ is about the variable (supernatant), that it can be fixed in +1 (that corresponds to $90 \mathrm{~mL}$ ). This condition is not the ideal, therefore the absorbance of the kinetic growth also increases, still with less intensity, but in then it does not remain another alternative. Yet, the variable $\mathrm{x}_{2}$ (temperature) presents practically the same contribution in the two models, being impossible to define a condition clearly favorable to the analytical reply (Figure 5).

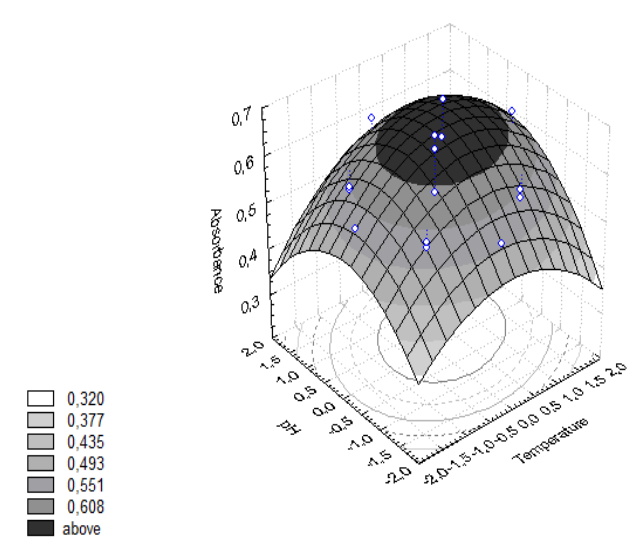

Figure 5- Response surface plot describing effect of temperature $\left({ }^{\circ} \mathrm{C}\right)$ and $\mathrm{pH}$.

\section{CONCLUSIONS}

The factorial planning demonstrated to be suitable for evaluating the average effect of the factors on the kinetic of growth of the pathogen microorganism. Inhibition of undesired pathogenic microorganism by LAB may be due to the effect of one, or synergism between several mechanisms. It was possible to observe strong influence of three factors that had inhibited the growth: supernatant, temperature, and pH.Despite the fact that this study appliedfractionary factorial planning to investigate the influence of the factors on the kinetic of growth pathogenic microorganisms.

It was possible to observe groups of microstructures that they had formed in function of the factors of the planning, what demonstrated the utility of this statistical tool when is desired to make exploratory research on variable whose effect is total or partially unknown. $L$. sakeiinhibited growth of a mixture of three strains of L. monocytogenes, E. coli and S. aureus used in our experiments.

These LAB strains should, therefore be adapted to growth in the products and to survive in the production facilities.

\section{RESUMO}

A atividade antimicrobiana de uma cultura comercial probiótica deLactobacillus sakei (ATCC 1521) foi 
avaliada em termos de concentração celular $(30,42,60$, 78 e $\left.90 \mathrm{mcg} / \mathrm{ml}, 10^{5}-10^{7} \mathrm{UFC} / \mathrm{mL}\right)$, temperatura de incubação $\left(4,10,20,30,37^{\circ} \mathrm{C}\right) \mathrm{e} \mathrm{pH}$ inicial do meio de cultura $(3.5,4.0,4.5,5.0$ e 5.5) contra três patógenos alimentares, Escherichia coli, Listeria monocytogenes e Staphylococcus aureus. O efeito antagônico da cultura probiótica in vitro foi realizada através da aplicação de método quantitativo espectrofotométrico. Os resultados indicaram que uma substância inibitória presente em caldo de cultura de 24 horas poderia ser vantajoso quando mantendo a cultura dominante durante fermentações mais prolongadas. Para a maior produção de ácido láctico $(1,04 \%$ v/v), o período de incubação da bactéria em caldo MRS foi de 24 horas em condições aeróbicas e a $37{ }^{\circ} \mathrm{C}$, com um valor de $\mathrm{pH}$ mínimo do sobrenadante $(3,5)$. Os dados sugerem que o sobrenadante pode ter atividade bacteriostática significativa contra E. coli,L. monocytogenes e $S$. aureus, e pode fornecer carnes curadas com um grau de protecção contra este microorganismo, particularmente se empregada com uma combinação de $\mathrm{pH}$ ácido, e de refrigeração adequada.

Palavras-chave:Atividade antimicrobiana, substratos complexos, superfície de resposta

\section{REFERENCES}

Box, G. E. P.; Hunter, W. G.; Hunter, J. S. (1978), Statistics for experimenters: An introduction to design, data analysis, and model building. In Bradley, R. A.; Hunter, J. S.; Kendall, D. G.; Watson, G. S. Eds., Wiley series in probability and mathematical statistics, Wiley, New York, 653p.

Brock, T. D.; Madigan, M. T.; Martinko, J. M.; Parker, J. (1994),Biology of Microorganisms. New Jersey: Prentice-Hall, 909p.

Cebeci, A. and Gurakan, C. (2003), Properties of potencial probiotic Lactobacillus plantarum strains, Food Microbiology,20, 511-518.

Chang, S. T.; Wu, J. H.; Wang, S. Y.; Kang, P. L.; Yang, N. S.; Shyur, L. F. (2001), Antioxidant activity of extracts from Acacia confusa bark and heartwood. Journal of Agricultural and Food Chemistry, 49: 3420-3424.

Hugas, M.; Garriga, M.; Aymerich, T.; Monfort, J. M. (1993), Biochemical characterization of lactobacilli from dry fermented sausages.International Journal of Food Microbiology, 18:107-113.
Hurst, A. (1983), Nisin and other inhibitory substances from lactic acid bacteria. In: BRANEN, A. L.; DAVIDSON, P. M. Ed. Antimicrobial in Foods. Marcel Deckker Inc., New York, USA, p. 327-351.

Jarvis, B. (1989), Statistical aspects of the microbiological analysis of foods. Elsevier Science Publishers, Amsterdam, The Netherlands.

Klaenhammer, T. R. (2001), Probiotics and prebiotics. In: Doyle, M. P.; Beuchat, L. R.; Montville, T. J. Food microbiology: fundamentals and frontiers. 2.ed. Washington: ASM, p. 797-811.

Koutsoumanis, K. P. and Sofos, J. N. (2005), Effect of inoculum size on the combined temperature, $\mathrm{pH}$ and $\mathrm{a}_{\mathrm{w}}$ limits for growth of Listeria monocytogenes. International Journal of Food Microbiology, 104:83-91.

Man, J. C.; Rogosa, M.; Sharpe, M. E. (1961).A medium for the cultivation ofLactobacilli.Journal of Applied Bacteriology,23:130-5.

Parker, R. B. (1974), Probiotics: the other half of the antibiotics story.Animal Nutrition and Health, 29, 4-8.

Schillinger, U.; Lücke, F. K. (1990), Lactic acid bacteria as protective cultures in meat products.Fleischwirtsch, 70, 1296-1299.

Shah, N. P. (2000), Probiotic bacteria: Selective enumeration and survival in dairy foods. JournalDairy Science, v.83, p.894-907.

Silva, N.; Junqueira, V. C. A.; Silveira, N. F. A. (2001), Manual de métodos de análise microbiológica de alimentos. 2. ed. São Paulo: Livraria Varela, 317p.

Vandenberg, P. A. (1993), Lactic acid bacteria, their metabolic products and interference with microbial growth. FEMS Microbiology Reviews, 12:221-238. 